Marquette University

e-Publications@Marquette

College of Education Faculty Research and

Publications

Education, College of

$3-1-2016$

\title{
Predicting Treatment Success in Child and Parent Therapy Among Families in Poverty
}

Ryan Mattek

Marquette University, ryan.mattek@marquette.edu

Robert A. Fox

Marquette University, robert.fox@marquette.edu

Sara E. Harris

Marquette University

Accepted version. The Journal of Genetic Psychology, Vol. 177, No. 2 (March/April 2016): 44-54.

DOI. (C) 2016 Taylor \& Francis (Routledge). Used with permission. 
NOT THE PUBLISHED VERSION; this is the author's final, peer-reviewed manuscript. The published version may be accessed by following the link in the citation at the bottom of the page.

\title{
Predicting Treatment Success in Child and Parent Therapy among Families in Poverty
}

\author{
Ryan J. Mattek \\ College of Education, Marquette University \\ Milwaukee, WI \\ Sara E. Harris \\ College of Education, Marquette University \\ Milwaukee, WI \\ Robert A. Fox \\ College of Education, Marquette University \\ Milwaukee, WI
}

\begin{abstract}
Behavior problems are prevalent in young children and those living in poverty are at increased risk for stable, high-intensity behavioral problems. Research has demonstrated that participation in child and parent therapy (CPT) programs significantly reduces problematic child behaviors while increasing positive behaviors. However, CPT programs, particularly those implemented with low-income populations, frequently report high rates of attrition (over 50\%). Parental attributional style has shown some promise as a contributing factor to treatment attendance and termination in previous research. The current study examined if parental attributional style could predict treatment success in a CPT program, specifically targeting low-income urban children with behavior problems. A hierarchical logistic regression was used with a sample of 425 families to assess if parent-referent and childreferent attributions variables predicted treatment success over and above
\end{abstract}


NOT THE PUBLISHED VERSION; this is the author's final, peer-reviewed manuscript. The published version may be accessed by following the link in the citation at the bottom of the page.

demographic variables and symptom severity. Parent referent attributions, child-referent attributions, and child symptom severity were found to be significant predictors of treatment success. Results indicated that caregivers who viewed themselves as a contributing factor for their child's behavior problems were significantly more likely to demonstrate treatment success. Alternatively, caregivers who viewed their child as more responsible for their own behavior problems were less likely to demonstrate treatment success. Additionally, more severe behavior problems were also predictive of treatment success. Clinical and research implications of these results are discussed.

\section{Introduction}

Psychopathology rates in preschool-aged children are similar to those found in later childhood, with Oppositional Defiant Disorder (ODD) and Attention Deficit Hyperactivity Disorder (ADHD) being the most common disorders found in preschool-aged children (Egger \& Angold, 2006; Lavigne, LeBailly, Hopkins, Gouze, \& Binns, 2009). These common childhood behavioral disorders are not transient occurrences and researchers suggest that they are moderately stable (Lavigne \& Arend, 1998; Tandon, Si, \& Luby, 2011). In addition, longitudinal studies tracking children from preschool age to early adolescence suggests that $17-27 \%$ of children experience persistent behavioral concerns (Cote, Vaillancourt, LeBlanc, Nagin, \& Tremblay, 2006; Fanti \& Henrich, 2010). Males, individuals from low-income families, and children raised by mothers without high school completion are at increased risk for stable, high-intensity behavioral problems (Cote et al., 2006; Fanti \& Henrich, 2010). Additionally, children who live in persistent poverty beginning in early childhood are also more likely to meet criteria for a psychiatric disorder upon school entry (Carter et al., 2010).

A number of evidence-based child and parent therapy (CPT) programs exist that focus on treating behavior problems by improving parenting practices. For the sake of this manuscript, CPT programs refer to programs that incorporate the child and parent in the therapeutic process, either together in a joint session or separately during treatment. Such programs include the Incredible Years Parent Training Program (Webster-Stratton, 1992) where parents are instructed in groups; Parent Child Interaction Therapy (Eyberg \& Boggs, 1989) where therapists provide instruction to parents and then

The Journal of Genetic Psychology, Vol. 177, No. 2 (March/April 2016): pg. 44-54. DOI. This article is (C) Taylor \& Francis (Routledge) and permission has been granted for this version to appear in e-Publications@Marquette. Taylor \& Francis (Routledge) does not grant permission for this article to be further copied/distributed or hosted elsewhere without the express permission from Taylor \& Francis (Routledge). 
have them practice new skills with their children while providing feedback through a "bug in the ear/one way mirror technology;" Triple-P Positive Parenting (Sanders, 1999), which can be delivered to groups, individuals, or in an online format;, and Early Pathways (Author citation, 2015), a home-based program for one family at a time where both the parent and child are present. The latter program also is unique in that it emphasizes families in poverty. While some of these other programs (e.g., Parent Child Interaction Therapy, Incredible Years Parent Training Program, and Early Pathways) have been used with low-income populations (e.g., Fernandez, Butler, \& Eyberg, 2011; Harris, Fox, \& Love, 2015; Reid, Webster-Stratton, \& Beauchaine, 2001), that has not been their primary population of interest. When CPT programs do work with low-income populations, premature termination from treatment continues to be a problem with approximately $50-60 \%$ rates of non-completion reported in these studies, with dropout typically being operationalized as lack of posttest measures.

Because of the high dropout rates, it is important to look at what factors predict treatment success so these factors could be considered and possibly addressed as a part of comprehensive treatment program. Parental attributions, in particular, are thought to play an important role in treatment participation (Corcoran \& Ivery, 2004; Peters, Calam, \& Harrington, 2005) and the overall quality of the parent-child relationship (Leung \& Slep, 2006; Snyder, Cramer, Afrank, \& Patterson, 2005; Sturge-Apple, Suor, \& Skibo, 2014; Wilson, Gardner, Burton, \& Leung, 2006).

\section{Attribution Theory, the Parent-Child Relationship, and Parent and Child Therapy}

Attribution theory was originally developed by Fritz Heider in the 1950s (Heider, 1958) and sought to explain how people form explanations for the causes of social behavior. Attribution theory can be classified into one of two categories: causal attributions and responsibility attributions. Causal attributions refer to explanations for the occurrence of an event and consist of four dimensions: locus (internal vs. external), stability (stable vs. unstable), controllability

The Journal of Genetic Psychology, Vol. 177, No. 2 (March/April 2016): pg. 44-54. DOI. This article is (C) Taylor \& Francis (Routledge) and permission has been granted for this version to appear in e-Publications@Marquette. Taylor \& Francis (Routledge) does not grant permission for this article to be further copied/distributed or hosted elsewhere without the express permission from Taylor \& Francis (Routledge). 
(controllable vs. uncontrollable), and generality (general vs. specific; Rotter, 1966; Weiner, 1986). Responsibility attributions do not explain why an event occurred, but rather, who should be held accountable for causing the event. It consists of three dimensions: intent (accidental vs. purposeful), motivation (the reason for action), and justifiability (whether the actions are proved reasonable by the mitigating circumstances; Snarr, Slep, \& Grande, 2009).

Within the parenting literature, responsibility attributions are typically called child-referent attributions (e.g., the parent perceives the child's disposition, judgment, or ability as being responsible for their behavior) and causal attributions are typically referred to as parent-referent attributions (e.g., the parent perceives their skill and competence as the cause of the child's behaviors). Child-referent attributions and parent-referent attributions can be either beneficial or detrimental to the parent-child relationship. Most parents attribute their child's prosocial behaviors to stable, dispositional traits within the child and view negative behaviors as temporary and situational (Corcoran \& Ivery, 2004). When a parent experiences a positive childreferent attribution (e.g., they perceive their child's compliance as a result of the child's good temperament and intelligence), it reinforces their own positive parent-referent attributions (e.g., they perceive themselves as a skilled and competent parent because they are able to facilitate the development of compliance in their child). Thus, the parent typically responds to their child in a manner that is positive and rewarding, in essence reinforcing both parties' attributions and behaviors. However, research has revealed that a negative attributional shift occurs in parents of children with behavior problems where they tend to attribute the cause of their child's negative to dispositional traits within the child (Corcoran \& Ivery, 2004; SturgeApple et al., 2014).

A growing body of research indicates a strong relationship between attributional style and a negative caregiver-child relationship (Leung \& Slep, 2006; Snyder et al., 2005; Sturge-Apple et al., 2014; Wilson et al., 2006). Negative child-referent attributions have been linked to more severe or punitive discipline strategies (Leung \& Slep, 2006; Sturge-Apple et al., 2014) and conduct problems in young children at home and in school (Wilson et al., 2006; Snyder et al., 2005). More specifically, parents that attribute their child's behaviors

The Journal of Genetic Psychology, Vol. 177, No. 2 (March/April 2016): pg. 44-54. DOI. This article is (C) Taylor \& Francis (Routledge) and permission has been granted for this version to appear in e-Publications@Marquette. Taylor \& Francis (Routledge) does not grant permission for this article to be further copied/distributed or hosted elsewhere without the express permission from Taylor \& Francis (Routledge). 
as more child-referent (within the child's control and intentionally provocative) are more likely to engage in harsh discipline practices (Sturge-Apple, et al., 2014). Negative parent-referent attributions have been linked to unsatisfying parenting experiences (Hageskull, Bohlin, \& Hammarberg, 2001), childhood behavior problems (Hageskull et al., 2001; Johnston, Hommersen, Seipp, 2009), and more authoritarian or permissive styles of parenting (Leung \& Slep, 2006).

Parental attributions have also been posited to play an important role in treatment attendance and early treatment success (Corcoran \& Ivery, 2004; Peters et al., 2005). This relationship may be particularly salient for CPT programs as the focus is on modifying the parenting practices of caregivers to change the behavior of their children, in essence, assigning some responsibility and causality to the parent. Thus, if parents attribute the child's behavior to child-referent attributions as opposed to parent-referent attributions they may be more likely to discontinue services that they perceive as incongruent with this belief. In fact, parents with more internal parent-referent attributional styles (i.e., they view their lack of parenting skills as the cause of their child's behavior problems) have been found more likely to complete treatment (Peters et al., 2005). On the opposite spectrum, higher dropout rates for parents with negative child-referent attributions have been reported (Miller \& Prinz, 2003). However, questions remain about the link between attributional style and engagement in treatment as other studies have found no relationship between parent-referent attribution styles and treatment participation (Nordstrom, Dumas, \& Gitter, 2008; Williford, Graves, Shelton, \& Woods, 2009). Mah and Johnston's (2008) review suggested that addressing parent cognitions within the context of CPT programs may help to increase treatment effectiveness and that the mixed findings in the research may be attributed to timing in which these attribution interventions are implemented (pre, during, post treatment) and specific types of attributions (attributions for misbehavior, acceptability of CPT programs, efficacy in parenting) that are assessed. Parental attributions related to reasons for child misbehavior were targeted in this study to determine if a significant effect was found and to assess the magnitude of the effect.

The Journal of Genetic Psychology, Vol. 177, No. 2 (March/April 2016): pg. 44-54. DOI. This article is (C) Taylor \& Francis (Routledge) and permission has been granted for this version to appear in e-Publications@Marquette. Taylor \& Francis (Routledge) does not grant permission for this article to be further copied/distributed or hosted elsewhere without the express permission from Taylor \& Francis (Routledge). 
There is a paucity of research regarding parent attributional styles across cultures or among families in poverty (e.g., Chavira \& Lopez, 2000; McCabe, Goehring, Yeh, \& Lau, 2008). Many of the empirical works examining the relationship between parental attributions and the treatment process also are conducted among populations of children age six years or older. Yet, four major CPT programs including the Incredible Years Parent Training Program (Webster-Stratton, 1992), Parent Child Interaction Therapy (Eyberg \& Boggs, 1989), Triple-P Positive Parenting (Sanders, 1999) and Early Pathways (Harris, Fox, \& Love, 2015) have established their effectiveness among populations of children five years of age and younger. Given the rapid cognitive, social, and emotional development that occurs in children in their early years, the difference in parenting techniques that are appropriate across that span, and the fact that parents' child-referent attributions are positively correlated with age (Wilson et al., 2006), the findings of attribution research on older children may not generalize to families of children under the age of 6 years. CPT research on children below the age of five is limited, but suggests that parental attributions may play an important role in treatment outcomes with young children (Dittman, Sanders, Farruggia, Palmer, \& Keown, 2014; Whittingham, Sofronoff, Sheffield, \& Sanders, 2009). These studies have examined how parent attributions have impacted treatment success in children with Autism Spectrum Disorders (Whittingham, Sofronoff, Sheffield, \& Sanders, 2009) and how parent attributions have impacted treatment success with an online parenting intervention (Dittman, Sanders, Farruggia, Palmer, \& Keown, 2014). It is also important to note that each study operationalized treatment success using different focuses, with Dittman et al. (2014) focusing on efficacy of parenting skills, whereas Whittingham et al. (2009) focused on attributions that parents ascribe to their children's negative behaviors. More research among families of children under the age of 6 years with diverse populations is needed to better understand how parental attributions affect treatment success.

The purpose of the current study was to explore what factors predicted treatment success in a CPT program. More specifically, the purpose was to determine if parental attributions predicted treatment success over and above demographic variables and child symptom severity. Our primary hypothesis was that parent attributions would be a significant predictor of treatment success.

The Journal of Genetic Psychology, Vol. 177, No. 2 (March/April 2016): pg. 44-54. DOI. This article is (C) Taylor \& Francis (Routledge) and permission has been granted for this version to appear in e-Publications@Marquette. Taylor \& Francis (Routledge) does not grant permission for this article to be further copied/distributed or hosted elsewhere without the express permission from Taylor \& Francis (Routledge). 
NOT THE PUBLISHED VERSION; this is the author's final, peer-reviewed manuscript. The published version may be accessed by following the link in the citation at the bottom of the page.

\section{Methods}

\section{Participants}

The participants were 425 families from a large urban area in the Midwest who were consecutively referred to and completed an intake evaluation at a clinic that was specifically developed to address mental health problems in young children (Author citation, 2007). Descriptive statistics for the sample can be found in Table 1 . The average age of the children was 3.20 years $(S D=1.03)$, including $65.6 \%$ boys from families most of whom received public assistance $(89.1 \%)$ indicating they met the federal definition of poverty. Of the children, 56.2\% were African American, 18.2\% Latino, 10.8\% Caucasian, and $14.8 \%$ were classified as multiracial. The majority of children met the criteria for a psychiatric diagnosis, with Oppositional Defiant Disorder being the most common (45.1\%). The average age of the primary caregiver was 29.66 years $(S D=8.49)$. Families were referred to the clinic by parents, other caregivers, individual health care providers, and over 75 community-based agencies. Eligibility criteria for this study included: (1) the child was under 6 years of age; (2) the referral source expressed significant behavioral or emotional concerns for the child; (3) the child did not have significant physical disabilities, serious medical conditions, or severe to profound intellectual disabilities; and (4) the child's parent or guardian signed a consent form approved by authors' Institutional Research Board. If the parent or guardian declined to participate in this research project, the same treatment program was offered to the family, but their data was not included in this study.

\section{EP Program}

The EP treatment program is an evidenced based CPT program. EP includes four core elements: (a) strengthening the parent-child relationship through child-led play; (b) helping parents maintain developmentally appropriate expectations for their child and learn cognitive strategies to respond calmly and thoughtfully to their child's challenging behaviors; (c) using positive reinforcement, teaching strategies, and establishing family routines to strengthen the child's pro-social behaviors; and (d) using limit-setting strategies to reduce the child's challenging behaviors, such as redirection, ignoring or timeout. The first four sessions typically focus on these psychoeducational

The Journal of Genetic Psychology, Vol. 177, No. 2 (March/April 2016): pg. 44-54. DOI. This article is (C) Taylor \& Francis (Routledge) and permission has been granted for this version to appear in e-Publications@Marquette. Taylor \& Francis (Routledge) does not grant permission for this article to be further copied/distributed or hosted elsewhere without the express permission from Taylor \& Francis (Routledge). 
components and additional sessions are designed to assist parents in implementing the concepts and strategies being taught. For example, in vivo problem-solving strategies are used in later sessions to adapt the treatment techniques to the child's home environment and instruction in skills to improve the child's listening and to create a safe and predictable home routine. Finally, strategies to manage challenging behaviors were introduced, including ignoring, redirection, limit setting, natural consequences, and time-outs; all forms of verbal and corporal punishment were strongly discouraged. Clinicians provided caregivers with behavior treatment plans with activities and a daily checklist to facilitate caregiver practice each week, which families completed and returned at the beginning of the subsequent session.

\section{Measures}

Demographic Questionnaire. The socio-demographic questionnaire was filled out by the clinician during the intake interview in order to obtain background information about the participants.

Early Childhood Behavior Screen (ECBS). The ECBS (Holtz \& Fox, 2012) is a 20-item rating scale that measures the parent perceptions of their child's positive and challenging behaviors in children under the age of 6 years. The ECBS consists of two empirically-derived scales: Pro-Social, 10 items that assess the frequency of positive child behaviors (listening) and Challenging, 10 items that assess the frequency of negative child behaviors (aggression). Items are rated on a 3-point frequency scale ( 2 = almost always/always, $1=$ sometimes, $0=$ rarely/never). The cut off for clinical significance is dependent on age of the child and was determined by receiver operating characteristic curve analysis using a clinical and non-clinical sample of children (Author Citation, 2015). The coefficient alphas for the Pro-Social and Challenging subscales were reported as .92 and .87 , respectively.

Parent Behavior Checklist (PBC). The PBC (Fox, 1994) is a 32-item rating scale designed to measure the behaviors and expectations of caregivers of children younger than the age of 6 years. The PBC consists of three empirically-derived scales from a norming sample of over 1,000 mothers from a large urban area: Expectations, Discipline (use of corporal and verbal punishment) and Nurturing. Items are rated using a 4-point frequency scale $(4=$ almost

The Journal of Genetic Psychology, Vol. 177, No. 2 (March/April 2016): pg. 44-54. DOI. This article is (C) Taylor \& Francis (Routledge) and permission has been granted for this version to appear in e-Publications@Marquette. Taylor \& Francis (Routledge) does not grant permission for this article to be further copied/distributed or hosted elsewhere without the express permission from Taylor \& Francis (Routledge). 
always/always, 3 = frequently, 2 = sometimes, and $1=$ almost never/never). Raw scores for each of the subscales are converted into standardized T-scores. An example item for the expectation scale is, "My child should be quiet when I am on the phone." An example item for the discipline scale is, "I yell at my child for whining". An example item for the nurturing scale is, "My child and I play together on the floor". The following coefficient alphas were reported for the PBC: Expectations $=.97$, Discipline $=.91$, and Nurturing $=.82$. Test-retest reliabilities for each of the three subscales were: Expectations $=.98$, Discipline $=.87$, and Nurturing $=.81$.

Parent Cognition Scale - Adapted (PCS-A). The PCS-A is an adapted version of the Parent Cognition Scale (Snarr et al., 2009); a 30-item measure that assesses the degree to which caregivers endorse dysfunctional child-referent and parent-referent attributions to explain their young child's challenging behavior. The original Parent Cognition Scale (PCS) was normed on 453 families of children age 3 to 7 years $(M=5.44$ years $), 18 \%$ of whom were identified as having externalizing behavior problems. The PCS consists of two empiricallyderived subscales: Child-Referent, 14 items that assess how frequently the caregiver makes child-referent responsibility attributions to explain their child's negative behaviors (e.g., "My child won't listen, My child thinks that he/she is the boss; My child is headstrong") and ParentReferent, 16 items that assess how frequently the caregiver makes parent-referent causal attributions to explain their child's negative behaviors (e.g., "I'm not structured enough with my child; I don't give my child enough attention; It's hard for me to set limits"). In other words, higher scores on the Parent-Referent subscale indicates that parents hold themselves responsible for their child's behaviors, whereas higher scores on the Child-Referent subscale indicates that the parents attribute misbehavior in their child to controllable dispositional traits. Items on the PCS are rated on a 6-point frequency scale ( 1 = always true, 2 = frequently true, $3=$ sometimes true, $4=$ occasionally true, $5=$ rarely true, $6=$ never true) with a range of 0-84 on the Child-Referent subscale and a range of 0-96 on the ParentReferent subscale. The Child-Referent and Parent-Referent subscales of the PCS report alpha coefficients of .89 and.83, respectively and test-retest reliability coefficients of .72 and .66 , respectively.

The Journal of Genetic Psychology, Vol. 177, No. 2 (March/April 2016): pg. 44-54. DOI. This article is (C) Taylor \& Francis (Routledge) and permission has been granted for this version to appear in e-Publications@Marquette. Taylor \& Francis (Routledge) does not grant permission for this article to be further copied/distributed or hosted elsewhere without the express permission from Taylor \& Francis (Routledge). 
The PCS-A retained the structure (i.e., child-referent and parent-referent attributions) and format (i.e., parent self-report on a frequency scale) of the PCS while making only minor modifications to simplify it for this study. First, the PCS-A was shortened to include only the 16 items from the PCS that were identified by confirmatory factor analysis as loading highly (i.e., between .55 - .80) on either one of the scales two factors (i.e., child-responsible attributions and parent-causal attribution), did not cross-load on the other factor, and did not have sizable or persistent residual covariances with items from the other factor (Snarr et al., 2009). Of these 16 items on the PCS-A, nine made up the Child-Referent subscale and seven make up the Parent-Referent subscale. Second, the response set on the PCS-A was shortened from a 6-point frequency scale to a 4-point frequency scale ( 1 = almost always the reason, 2 = frequently the reason, $3=$ sometimes the reason, $4=$ almost never the reason) to simplify the response-selection process to accommodate a less-educated participant sample. Based on the present sample, the Child-Referent and Parent-Referent subscales of the PCS-A had alpha coefficients of .83 and .80 respectively.

\section{Procedures}

Parents referred for this study provided consent at the initial intake interview for themselves and their children to participate. After parents consented to participate, the intake evaluation was completed which included the collection of the study's pretest measures. When a formal termination session was scheduled, the posttest measures included the ECBS, the PBC, and the PCS-A. Operationalization of treatment success should consider current research, demographic and contextual variables of the target sample, and provide adequate detail for replication and comparison across studies. Arbitrarily using completion of a post-treatment session may not capture clients who made significant change but chose to discontinue services after the change was obtained, which is a stance supported by the dose-effect literature (see Barkham et al., 2006 for a full discussion). Families with low socioeconomic status (SES) often drop out of CPT treatment due to several contextual factors, and as a result, many families who may be successful in treatment are lost to attrition because they lack a formal post-test (Author Citation, 2009). A reliable change index (RCI; Jacobson \& Truax, 1991) of the primary outcome measure has

The Journal of Genetic Psychology, Vol. 177, No. 2 (March/April 2016): pg. 44-54. DOI. This article is (C) Taylor \& Francis (Routledge) and permission has been granted for this version to appear in e-Publications@Marquette. Taylor \& Francis (Routledge) does not grant permission for this article to be further copied/distributed or hosted elsewhere without the express permission from Taylor \& Francis (Routledge). 
been recommended to supplement the treatment duration component (Swift, Callahan, \& Levine, 2009). This involves administering the primary outcome measure at every session in order to obtain comparison data and offers a logically valid and reliable measure of client improvement during treatment (Swift et al., 2009). The RCI is more conservative than using change score alone as the outcome, as it accounts statistically for chance and helps to provide an index of clinical significance as opposed to statistical significance alone (refer to Zahra \& Hedge, 2010 for a full discussion).

Following the recommendations for best practice by Swift et al. (2009), a multi-method approach was used to operationalize the construct of treatment success. Under this definition, participants needed to meet two criteria in order to be considered to have treatment success: 1 ) the child must demonstrate reliable change calculated according to the Jacobson and Traux's (1991) reliable change method on the ECBS Challenging scale from their pretest score to their last obtained score; 2) the child and caregiver must attend three or more treatment sessions after the initial intake assessment. In the sample $45.5 \%$ of participants met the RCI criteria by the third treatment session and $60.2 \%$ of the participants met the treatment duration criteria. Using treatment duration and RCI criteria, $40.5 \%$ of the participants met the requirements for the outcome measure of treatment success. Table 2 displays the demographics of the groups that met criteria for early treatment success and those who did not meet early treatment success criteria. The average number of session attended for the early treatment success group was $8.78(S D=3.79)$, and the average number of sessions attended for those who did not meet early treatment success criteria was $4.18(S D=3.22)$.

\section{Results}

A hierarchical logistic regression was conducted to assess if PCS variables predicted treatment success over and above demographic variables and symptom severity. Demographic variables including child age, child race, child's gender, family income, and parent use of corporal punishment were controlled for in the first step. These variables were entered into the first step as they can be conceptualized as part of the child's background. Additionally, since the relationship between corporal punishment and parental attributions is well established, it was important to control for to prevent potential

The Journal of Genetic Psychology, Vol. 177, No. 2 (March/April 2016): pg. 44-54. DOI. This article is (C) Taylor \& Francis (Routledge) and permission has been granted for this version to appear in e-Publications@Marquette. Taylor \& Francis (Routledge) does not grant permission for this article to be further copied/distributed or hosted elsewhere without the express permission from Taylor \& Francis (Routledge). 
confounding of the relationship between parental attributions and early treatment success. Child symptom severity based on the ECBS Challenging scale score was entered on the second block of the regression, and both scales of the PCS were entered on the third block of the regression. These were entered to see if their inclusion added prediction over and above the demographic variables. The correlations among continuous variables can be found in Table 3 . The overall model summary results for each block of the hierarchical logistic regression are included in Table 4.

The model containing all of the predictors in block 1 was not found to be statistically significant $\left(X^{2}[7, \mathrm{~N}=387]=2.83, p>.05\right)$, indicating that the model was unable to distinguish between participants who were successful in treatment and those who were unsuccessful. The block 1 model, as a whole, explained between $0.70 \%$ (Cox and Snell R square) and 1.0\% (Nagelkerke R Square) of the null deviance in treatment success. As shown in Table 5, none of the predictor variables made a statistically significant contribution to the model.

The model containing all of the predictors in block 2 was statistically significant $\left(X^{2}[8, \mathrm{~N}=387]=24.47, \mathrm{p}<.01\right)$, indicating that the model was able to distinguish between participants who were successful in treatment and those who were unsuccessful. The model as a whole explained between $6.10 \%$ (Cox and Snell R square) and $8.60 \%$ (Nagelkerke R Square) of the null deviance in treatment success. As shown in Table 5 , child symptom severity was a significant predictor.

The full model containing all of the predictors was statistically significant $\left(x^{2}[10, \mathrm{~N}=387]=38.10, \mathrm{p}<.001\right)$, indicating that the model was able to distinguish between participants who were successful in treatment and those who were unsuccessful. The model, as a whole, explained between $9.40 \%$ (Cox and Snell R square) and $13.20 \%$ (Nagelkerke R Square) of the null deviance in treatment success and correctly classified $69.50 \%$ of cases. As shown in Table 5, three of the independent variables made a unique statistically significant contribution to the full model (child symptom severity, parent-referent attributions, and child-referent attributions). 
NOT THE PUBLISHED VERSION; this is the author's final, peer-reviewed manuscript. The published version may be accessed by following the link in the citation at the bottom of the page.

\section{Discussion}

The current study sought to continue previous efforts to disentangle the multitude of potential factors related to early treatment termination in child and parent therapy programs (Nock \& Ferriter, 2005) by studying one variable, namely parent attributions, in a relatively large diverse sample of very young children living in poverty. A hierarchical logistic regression analysis, which controlled for demographic variables, revealed that variables such as child age, child race, child's gender, family income, and parent use of corporal punishment were not significant predictors of treatment success. However, child symptom severity, child-referent attributions, and parent referent attributions were all found to be significantly predictive of treatment success, with child symptom severity and child referent attributions being negatively related to early treatment success and parent referent attributions being positively related to early treatment success. In other words, caregivers who at intake viewed themselves as the cause of their child's negative behaviors, as reflected by higher scores on the PCS-A were significantly more likely to be classified as meeting early treatment success criteria. Caregivers who at intake viewed their child as more responsible for their own behavior problems were significantly more likely to be classified as not attaining early treatment success criteria, which required that they meet the criteria for the RCI index using an assessment measure of the child's challenging behavior (the EBCS -Challenging scale) and attend at least three sessions. This suggests that interventions targeted at helping parents to acknowledge ways in which their own behaviors and parenting style maybe influencing the behaviors of their children may be linked with a reduction of challenging behaviors and increase the likelihood of continuing to attend treatment.

Results of the non-significance of demographic variables in treatment success are consistent with the current body of literature (Boggs et al., 2004; Fox \& Holtz, 2009; Marcynyszyn, Maher, \& Corwin, 2011; McCabe \& Yeh, 2009; Sanders \& McFarland, 2000; Werba, Eyberg, Boggs, \& Algina, 2006). Consequently, this demographic information that is normally collected during the first intake session, is unlikely to be helpful in determining whether or not a family will persevere through the treatment program. The results also indicated that parents who viewed their children's behaviors as more

The Journal of Genetic Psychology, Vol. 177, No. 2 (March/April 2016): pg. 44-54. DOI. This article is (C) Taylor \& Francis (Routledge) and permission has been granted for this version to appear in e-Publications@Marquette. Taylor \& Francis (Routledge) does not grant permission for this article to be further copied/distributed or hosted elsewhere without the express permission from Taylor \& Francis (Routledge). 
problematic at pretest were significantly more likely to be successful in treatment when controlling for other factors in the model. This finding may be that these parents of children are in greater distress because their child's behavior and as a result, are more motivated to participate in evidence-based programs that may reduce these behavior problems.

Results from parent-referent and child-referent attributions are in line with previous research findings (Miller \& Prinz, 2003; Peters et al., 2005; Whittingham, Sofronoff, Sheffield, \& Sanders, 2009), suggesting that previous findings may have some generalizability in predominantly low-income minority families of very young children. Parents that viewed their current parenting skills as a contributing factor to their child's behavior problems were more likely to meet treatment success criteria. Alternatively, parents that viewed their child's behavior as within the child's control and intentionally provocative were less likely to complete the treatment program. This finding may be related to parental beliefs that because the problem lies within the child (i.e., as opposed to the parent), treatment should target the child exclusively (e.g., play therapy).

\section{Implications and Limitations}

The finding that parental beliefs regarding the origins of their child's behavior problems affect their participation in treatment programs is important. Clinicians may spend significant time and effort in implementing CPT programs with these families without success. Consequently, clinicians who encounter these families, may find their time better spent discussing parental attribution beliefs rather than starting an evidence-based CPT programs. Moreover, failure to address this potentially significant barrier to treatment, may result in early treatment termination and most importantly, allow the young child's behavior problems to worsen and become more intractable over time.

However, prior to assuming that parent attributions may be one of several variables that cause early treatment termination, more research is needed. Without a randomized controlled trial (RCT), causal attributions on the effect of parental attributions' role on early treatment success cannot be made and findings should be interpreted in light of this limitation. A RCT with the experimental group receiving attribution retraining prior to CPT treatment would strengthen the

The Journal of Genetic Psychology, Vol. 177, No. 2 (March/April 2016): pg. 44-54. DOI. This article is (C) Taylor \& Francis (Routledge) and permission has been granted for this version to appear in e-Publications@Marquette. Taylor \& Francis (Routledge) does not grant permission for this article to be further copied/distributed or hosted elsewhere without the express permission from Taylor \& Francis (Routledge). 
argument that families may require pre-treatment services to better prepare them to be successful in evidence-based CPT programs. Questions surrounding when these attributions should be addressed during treatment (pre, during, or post) and what attributions should be targeted (responsibility for child misbehavior, acceptability of CPT programs) also remain (Mah \& Johnston, 2008), and should be considered in future research.

\section{Acknowledgements}

This research was supported in part by grants from Aurora Health Care Better Together Fund, Charles D. Jacobus Family Foundation, Exchange Clubs of Greater Milwaukee Charitable Foundation, Greater Milwaukee Foundation, Helen Bader Foundation, Hearst Foundation, Roger and Cindy Schaus Family, United Way and the Zilber Family Foundation.

Correspondence concerning this article should be addressed to Robert A. Fox, Professor, Marquette University, Department of Counselor Education and Counseling Psychology, College of Education, Schroeder Complex, P. O. Box 1881, Milwaukee WI 53201-1881. E-mail: robert.fox@marquette.edu; Phone: 414-288-1469.

\section{References}

Barkham, M., Connell, J., Stiles, W. B., Miles, J. N. V., Margison, F., Evans, C., \& Mellor-Clark, J. (2006). Dose-effect relations and responsive regulation of treatment duration: The good enough level. Journal of Consulting and Clinical Psychology, 74(1), 160-167.

Boggs, S. R., Eyberg, S. M., Edwards, D., Rayfield, A., Jacobs, J., Bagner, D., \& Hood, K. (2004). Outcomes of parent-child interaction therapy: A comparison of dropouts and treatment completers one to three years after treatment. Child \& Family Behavior Therapy, 26(4), 1-22. doi: http://dx.doi.org/10.1300/J019v26n04_01

Carter, A. S., Wagmiller, R. J., Gray, S. O., McCarthy, K. J., Horwitz, S. M., \& Briggs-Gowan, M. J. (2010). Prevalence of DSM-IV disorder in a representative, healthy birth cohort at school entry: Sociodemographic risks and social adaptation. Journal of the American Academy of Child \& Adolescent Psychiatry, 49(7), 686-698.

The Journal of Genetic Psychology, Vol. 177, No. 2 (March/April 2016): pg. 44-54. DOI. This article is (C) Taylor \& Francis (Routledge) and permission has been granted for this version to appear in e-Publications@Marquette. Taylor \& Francis (Routledge) does not grant permission for this article to be further copied/distributed or hosted elsewhere without the express permission from Taylor \& Francis (Routledge) 
NOT THE PUBLISHED VERSION; this is the author's final, peer-reviewed manuscript. The published version may be

accessed by following the link in the citation at the bottom of the page.

Chavira, V., \& Lopez, S. R. (2000). Latina Mothers' Attributions, Emotions, and Reactions to the Problem Behaviors of their Children with Developmental Disabilities. Journal Of Child Psychology \& Psychiatry \& Allied Disciplines, 41, 245-252. doi: 10.1111/1469-7610.00605

Corcoran, J. \& Ivery, J. (2004). Parent and child attributions for child behavior: Distinguishing factors for engagement and outcome. Families in Society, 85, 101-106. doi: http://dx.doi.org/10.1606/10443894.259

Cote, S. M., Vaillancourt, T., LeBlanc, J. C., Nagin, D. S., \& Tremblay, R. E. (2006). The development of physical aggression from toddlerhood to pre-adolescence: A nationwide longitudinal study of Canadian children. Journal of Abnormal Child Psychology, 34, 71-85. doi:10.1007/s10802-005-9001-z

Dittman, C. K., Sanders, M. R., Farruggia, S. P., Palmer, M. L., \& Keown, L. J. (2014). Predicting success in an online parenting intervention: The role of child, parent, and family factors. Journal of Family Psychology, 28, 236-243. doi:10.1037/a0035991

Egger, H. L., \& Angold, A. (2006). Common emotional and behavioral disorders in preschool children: Presentation, nosology, and epidemiology. Journal of Child Psychology and Psychiatry, 47, 313337. doi: http://dx.doi.org/10.1111/j.1469-7610.2006.01618.x

Eyberg, S. M., \& Boggs, S. R. (1989). Parent training for oppositional-defiant preschoolers. In C. E. Schaefer \& J. M. Briesmeister (Eds.), Handbook of parent training: Parents as co-therapists for children's behavior problems (pp. 105-132). New York: Wiley.

Fanti, K. A., \& Henrich, C. C. (2010). Trajectories of pure and co-occurring internalizing and externalizing problems from age 2 to age 12: Findings from the national institute of child health and human development study of early child care. Developmental Psychology, 46, 1159-1175. doi: http://dx.doi.org/10.1037/a0020659

Fernandez, M.A., Butler, A., \& Eyberg, S.M. (2011). Treatment outcomes for low socioeconomic status African American families in parent-child interaction therapy: A pilot study. Child and Family Behavior Therapy, 33, 32-48. doi: 10.1080/07317107.2011.545011

Fox, R. A. (1994). Parent behavior checklist. Austin, TX: ProEd (Currently available from the author, Marquette University, School of Education, P.O. Box 1881, Milwaukee, WI 53201-1881; Email: robert.fox@marquette.edu).

The Journal of Genetic Psychology, Vol. 177, No. 2 (March/April 2016): pg. 44-54. DOI. This article is (C) Taylor \& Francis (Routledge) and permission has been granted for this version to appear in e-Publications@Marquette. Taylor \& Francis (Routledge) does not grant permission for this article to be further copied/distributed or hosted elsewhere without the express permission from Taylor \& Francis (Routledge). 
NOT THE PUBLISHED VERSION; this is the author's final, peer-reviewed manuscript. The published version may be accessed by following the link in the citation at the bottom of the page.

Fox, R. A., \& Holtz, C. A. (2009). Treatment outcomes for toddlers with behavior problems from families in poverty. Child and Adolescent Mental Health, 14, 183-189. doi: 10.1111/j.1475-3588.2009.00527.x

Hageskull, B., Bohlin, G., \& Hammarberg, A. (2001). The role of parental perceived control in child development: A longitudinal study. International Journal of Behavioral Disorders, 25, 429-437. doi: $10.1080 / 016502501316934851$

Harris, S. E., Fox, R.A., \& Love, J.R. (2015). Early Pathways therapy for young children in poverty: A randomized controlled trial. Counseling Outcome Research and Evaluation, 6, 3-17. doi: $10.1177 / 2150137815573628$

Heider, F. (1958). The psychology of interpersonal relations. New York: Wiley Holtz, C. A., \& Fox, R. A. (2012). Behavior problems in young children from low-income families: The development of a new screening tool. Infant Mental Health Journal, 33, 82-94. doi:10.1002/imhj.20341

Jacobson, N. S., \& Truax, P. (1991). Clinical significance: A statistical approach to defining meaningful change in psychotherapy research. Journal of Consulting and Clinical Psychology, 59, 12-19. doi: http://dx.doi.org/10.1037/0022-006X.59.1.12

Johnston, C., Hommersen, P., \& Seipp, C. M. (2009). Maternal Attributions and Child Oppositional Behavior: A Longitudinal Study of Boys with and without Attention-Deficit/Hyperactivity Disorder. Journal of Consulting and Clinical Psychology, 77(1), 189-195. doi: $10.1037 / \mathrm{a} 0014065$

Lavigne, J. V., LeBailly, S. A., Hopkins, J., Gouze, K. R., \& Binns, H. J. (2009). The prevalence of ADHD, ODD, depression, and anxiety in a community sample of 4-year-olds. Journal of Clinical Child \& Adolescent Psychology, 38, 315-328. doi: $10.1080 / 15374410902851382$

Leung, D. W., \& Slep, A. S. (2006). Predicting inept discipline: the role of parental depressive symptoms, anger, and attributions. Journal of Consulting and Clinical Psychology, 74, 524-534. doi: 10.1037/0022006X.74.3.524

Mah, J., \& Johnston, C. (2008). Parental social cognitions: Considerations in the acceptability of and engagement in behavioral parent training. Clinical Child \& Family Psychology Review, 11(4), 218-236. doi: $10.1007 / \mathrm{s} 10567-008-0038-8$

The Journal of Genetic Psychology, Vol. 177, No. 2 (March/April 2016): pg. 44-54. DOI. This article is (C) Taylor \& Francis (Routledge) and permission has been granted for this version to appear in e-Publications@Marquette. Taylor \& Francis (Routledge) does not grant permission for this article to be further copied/distributed or hosted elsewhere without the express permission from Taylor \& Francis (Routledge). 
NOT THE PUBLISHED VERSION; this is the author's final, peer-reviewed manuscript. The published version may be

accessed by following the link in the citation at the bottom of the page.

McCabe, K.M., Goehring, K., Yeh, M., \& Lau, A.S. (2008). Parenting locus of control and externalizing behavior problems among Mexican American preschoolers. Journal of Emotional and Behavioral Disorders, 16, 118126. doi: $10.1177 / 1063426608315139$

McCabe, K. M., \& Yeh, M. (2009). Parent-child interaction therapy for Mexican Americans: A randomized clinical trial. Journal of Clinical Child and Adolescent Psychology, 38, 753-759. doi: $10.1080 / 15374410903103544$

Marcynyszyn, L. A., Maher, E. J., \& Corwin, T. W. (2011). Getting with the (evidence-based) program: An evaluation of the incredible years parent training program in child welfare. Children and Youth Services Review, 33, 747-757. doi: 10.1016/j.childyouth.2010.11.021

Miller, G. E., \& Prinz, R. J. (2003). Engagement of families in treatment for childhood conduct problems. Behavior Therapy, 34, 517-534. doi: 10.1016/S0005-7894(03)80033-3

Nock, M. K., \& Ferriter, C. (2005). Parent management of attendance and adherence in child and adolescent therapy: A conceptual and empirical review. Clinical Child and Family Psychology Review, 2, 149-166. doi: 10.1007/s10567-005-4753-0

Nordstrom, A. H., Dumas, J. E., \& Gitter, A. H. (2008). Parental attributions and perceived intervention benefits and obstacles as predictors of maternal engagement in a preventive parenting program. NHSA Dialogue, 11, 1-24. doi:10.1080/15240750701816439

Peters, S. Calam, R., \& Harrington, R. (2005). Maternal attributions and expressed emotion as predictors of attendance at parent management training. Journal of Child Psychology and Psychiatry, 46, 436-448. doi: 10.1111/j.1469-7610.2004.00365.x

Reid, M. J., Webster-Stratton, C., \& Beauchaine, T. P. (2001). Parent training in head start: A comparison of program response among African American, Asian American, Caucasian, and Hispanic mothers. Prevention Science, 2, 209-227. doi: 10.1023/A:1013618309070

Rotter, J. (1966). Generalized expectancies for internal versus external control of reinforcements. Psychological Monographs : General and Applied, 80, 1-28. doi: http://dx.doi.org/10.1037/h0092976

Sanders, M. R. (1999). Triple P-Positive Parenting Program: Towards an empirically validated multilevel parenting and family support strategy for the prevention of behavior and emotional problems in children.

The Journal of Genetic Psychology, Vol. 177, No. 2 (March/April 2016): pg. 44-54. DOI. This article is (C) Taylor \& Francis (Routledge) and permission has been granted for this version to appear in e-Publications@Marquette. Taylor \& Francis (Routledge) does not grant permission for this article to be further copied/distributed or hosted elsewhere without the express permission from Taylor \& Francis (Routledge). 
NOT THE PUBLISHED VERSION; this is the author's final, peer-reviewed manuscript. The published version may be accessed by following the link in the citation at the bottom of the page.

Clinical Child \& Family Psychology Review, 2, 71-90. doi: 10.1023/A: 1021843613840

Snarr, J. D., Slep, A. S., \& Grande, V. P. (2009). Validation of a new selfreport measure of parental attributions. Psychological Assessment, 21, 390-401. doi: 10.1037/a0016331

Snyder, J., Cramer, A., Afrank, J., \& Patterson, G. R. (2005). The contributions of ineffective discipline and parental hostile attributions of child misbehavior to the development of conduct problems at home and school. Developmental Psychology, 41, 30-41. doi: 10.1037/0012-1649.41.1.30

Sturge-Apple, M. L., Suor, J. H., \& Skibo, M. A. (2014). Maternal childcentered attributions and harsh discipline: The moderating role of maternal working memory across socioeconomic contexts. Journal of Family Psychology, 28, 645-654. doi:10.1037/fam0000023

Swift, J.K., Callahan, J.L., \& Levine, J.C. (2009). Using clinically significant change to identify premature termination. Psychotherapy: Theory, Research, Practice, Training, 46, 328-335. doi: 10.1037/a0017003

Tandon, M., Si, X., \& Luby, J. (2011). Preschool onset attentiondeficit/hyperactivity disorder: Course and predictors of stability over 24 months. Journal of Child and Adolescent Psychopharmacology, 21, 321-330. doi:10.1089/cap.2010.0045

Webster-Stratton, C. (1992). The Incredible Years: A trouble-shooting guide for parents of children age 3-8 years. Toronto: Umbrella Press.

Weiner, B. (1986). An attributional theory of motivation and emotion. New York: Springer-Verlag.

Werba, B., Eyberg, S. M., Boggs, S. R., \& Algina, J. (2006). Predicting the outcome of parent-child interaction therapy: Success and attrition. Behavior Modification, 30, 618-646. doi: 10.1177/0145445504272977

Williford, A.P., Graves, K.N., Shelton, T.L., \& Woods, J.E. (2009)., 4, 225237. doi: $10.1016 /$ j.cpr.2012.10.010

Wilson, C., Gardner, F., Burton, J., \& Leung, S. (2006). Maternal attributions and young children's conduct problems: A longitudinal study. Infant and Child Development, 15, 109-121. doi: 10.1002/icd.440

Whittingham, K., Sofronoff, K., Sheffield, J., \& Sanders, M. R. (2009). Do parental attributions affect treatment outcome in a parenting program? An exploration of the effects of parental attributions in an

The Journal of Genetic Psychology, Vol. 177, No. 2 (March/April 2016): pg. 44-54. DOI. This article is (C) Taylor \& Francis (Routledge) and permission has been granted for this version to appear in e-Publications@Marquette. Taylor \& Francis (Routledge) does not grant permission for this article to be further copied/distributed or hosted elsewhere without the express permission from Taylor \& Francis (Routledge). 
NOT THE PUBLISHED VERSION; this is the author's final, peer-reviewed manuscript. The published version may be accessed by following the link in the citation at the bottom of the page.

RCT of stepping stones triple p for the ASD population. Research in Autism Spectrum Disorders, 3, 129-144.

Zahra, D. \& Hedge, C. (2010). The reliable change index: Why isn't it more popular in academic psychology? PsyPag, 76, 14-19.

The Journal of Genetic Psychology, Vol. 177, No. 2 (March/April 2016): pg. 44-54. DOI. This article is (C) Taylor \& Francis (Routledge) and permission has been granted for this version to appear in e-Publications@Marquette. Taylor \& Francis (Routledge) does not grant permission for this article to be further copied/distributed or hosted elsewhere without the express permission from Taylor \& Francis (Routledge). 
NOT THE PUBLISHED VERSION; this is the author's final, peer-reviewed manuscript. The published version may be accessed by following the link in the citation at the bottom of the page.

\section{Table 1}

\section{Descriptive Statistics of Sample}

\section{Variable}

Child Characteristics

Age $(M, S D)$

$3.20(1.03)$

Sex (\% female)

34.4

Race (\%)

African American

Latino/a

Caucasian

Multiracial

Primary Caregiver Characteristics

Age $(M, S D)$

Public Assistance (\%)

Measures

ECBS-Challenging $(M, S D)$

PBC-Discipline $(M, S D)$

PCS-A Parent $(M, S D)$

PCS-A Child $(M, S D)$
56.2

18.2

10.8

14.8

The Journal of Genetic Psychology, Vol. 177, No. 2 (March/April 2016): pg. 44-54. DOI. This article is (C) Taylor \& Francis (Routledge) and permission has been granted for this version to appear in e-Publications@Marquette. Taylor \& Francis (Routledge) does not grant permission for this article to be further copied/distributed or hosted elsewhere without the express permission from Taylor \& Francis (Routledge). 
NOT THE PUBLISHED VERSION; this is the author's final, peer-reviewed manuscript. The published version may be accessed by following the link in the citation at the bottom of the page.

\section{Table 2}

\section{Demographics of Groups that met and did not meet Early Treatment Success Criteria}

Early Treatment Success Met Early Treatment Success not Met

\begin{tabular}{lllllllllll}
\cline { 2 - 6 } & Variable & $M$ & $S D$ & $n$ & $\%$ & $M$ & $S D$ & $n$ & $\%$
\end{tabular}

Child Characteristics

$\begin{array}{lllllll}\text { Age of Child } & 3.22 & 1.04 & 172 & 3.17 & 1.02 & 253\end{array}$

Gender

Female

60

34.9

86

34.0

Male

$112 \quad 65.1$

Race

African American

Latino/a

Caucasian

Multiracial

Primary Caregiver Characteristics
30.28

8.28
$90 \quad 52.3$

149

58.9

35

20.3

17

30
Age of Primary Caretaker

Public Assistance
17.4

33

13.0
$42 \quad 16.6$

29

11.5

29.25

8.32 
NOT THE PUBLISHED VERSION; this is the author's final, peer-reviewed manuscript. The published version may be accessed by following the link in the citation at the bottom of the page.

\section{Table 3}

Correlations among Continuous Variables in the Hierarchical Logistic Regression

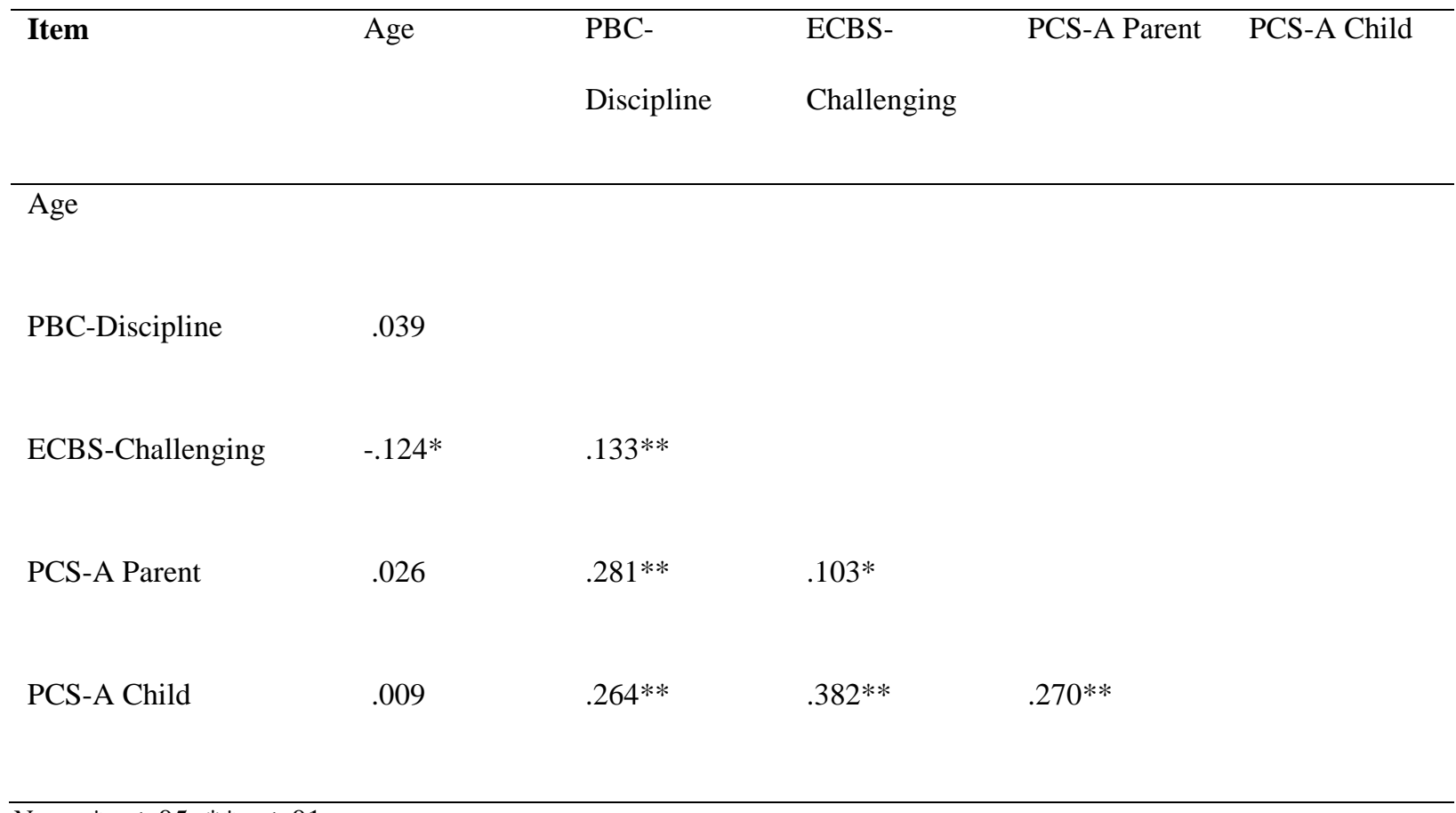

Note: $* p \leq .05 ; * p \leq .01$

The Journal of Genetic Psychology, Vol. 177, No. 2 (March/April 2016): pg. 44-54. DOI. This article is (C) Taylor \& Francis (Routledge) and permission has been granted for this version to appear in e-Publications@Marquette. Taylor \& Francis (Routledge) does not grant permission for this article to be further copied/distributed or hosted elsewhere without the express permission from Taylor \& Francis (Routledge). 
NOT THE PUBLISHED VERSION; this is the author's final, peer-reviewed manuscript. The published version may be accessed by following the link in the citation at the bottom of the page.

\section{Table 4}

\section{Model Summaries}

\begin{tabular}{|c|c|c|c|c|c|c|c|c|}
\hline & \multicolumn{3}{|c|}{ Omnibus } & \multicolumn{3}{|c|}{ Hosmer \& Lemeshow } & \multirow{2}{*}{$\begin{array}{r}\text { Cox \& Snell } \\
R^{2}\end{array}$} & \multirow{2}{*}{$\begin{array}{r}\text { Nagelkerke } \\
\qquad R^{2}\end{array}$} \\
\hline & $\chi^{2}$ & $d f$ & $p$ & $\chi^{2}$ & $d f$ & $p$ & & \\
\hline Block 1 & 2.83 & 7 & .900 & 5.59 & 8 & .694 & .007 & .010 \\
\hline Block 2 & 21.65 & 1 & $.000 *$ & 13.01 & 8 & .112 & .061 & 086 \\
\hline Block 3 & 13.62 & 2 & $.001 *$ & 8.78 & 8 & .361 & .094 & .132 \\
\hline
\end{tabular}

Note: ${ }^{*} p \leq .001$

The Journal of Genetic Psychology, Vol. 177, No. 2 (March/April 2016): pg. 44-54. DOI. This article is (C) Taylor \& Francis (Routledge) and permission has been granted for this version to appear in e-Publications@Marquette. Taylor \& Francis (Routledge) does not grant permission for this article to be further copied/distributed or hosted elsewhere without the express permission from Taylor \& Francis (Routledge). 
NOT THE PUBLISHED VERSION; this is the author's final, peer-reviewed manuscript. The published version may be accessed by following the link in the citation at the bottom of the page.

\section{Table 5}

Hierarchical Logistic Regression Analysis of Treatment Success

$95 \%$ C.I.

Predictor

df $\quad$ Wald $\quad p$

$B$

Odds

Lower Upper

\section{Block 1}

Age

$1 \quad 0.34 \quad .558$

.06

1.07

0.86

1.31

African American

\section{1}

$2.06 \quad .151$

$-.44$

0.64

0.35

1.18

Latino

$$
1
$$

Caucasian

$$
1
$$

0.86

.353

0.71

0.34

1.47

Gender

$$
1
$$

$0.19 \quad 667$

$-.42$

0.66

0.27

1.59

Public Assistance

1

.536

.10

1.10

0.70

1.74

PBC Discipline

$1 \quad 0.00 \quad .973$

1.26

0.61

\section{Block 2}

$\begin{array}{lccccccc}\text { Age } & 1 & 1.45 & .228 & .14 & 1.11 & 0.92 & 1.43 \\ \text { African American } & 1 & 0.32 & .054 & -.62 & 0.54 & 0.29 & 1.01 \\ \text { Latino } & 1 & 0.36 & .549 & -.23 & 0.79 & 0.37 & 1.69 \\ \text { Caucasian } & 1 & 0.36 & .550 & -.28 & 0.76 & 0.30 & 1.89 \\ \text { Gender } & 1 & 1.91 & .168 & .34 & 1.40 & 0.87 & 2.26 \\ \text { Public Assistance } & 1 & 0.00 & .994 & -.00 & 1.00 & 0.46 & 2.14 \\ \text { PBC Discipline } & 1 & 0.18 & .668 & -.01 & 1.00 & 0.97 & 1.02 \\ \text { ECBS Challenging } & 1 & 19.64 & .000^{* *} & .14 & 1.15 & 1.08 & 1.22\end{array}$

The Journal of Genetic Psychology, Vol. 177, No. 2 (March/April 2016): pg. 44-54. DOI. This article is (C) Taylor \& Francis (Routledge) and permission has been granted for this version to appear in e-Publications@Marquette. Taylor \& Francis (Routledge) does not grant permission for this article to be further copied/distributed or hosted elsewhere without the express permission from Taylor \& Francis (Routledge). 
NOT THE PUBLISHED VERSION; this is the author's final, peer-reviewed manuscript. The published version may be accessed by following the link in the citation at the bottom of the page.

\section{Block 3}

\begin{tabular}{|c|c|c|c|c|c|c|c|}
\hline Age & 1 & 1.58 & .208 & .14 & 1.15 & 0.92 & 1.44 \\
\hline African American & 1 & 3.21 & .073 & -.59 & 0.56 & 0.29 & 1.06 \\
\hline Latino & 1 & 0.66 & .418 & -.32 & 0.73 & 0.34 & 1.57 \\
\hline Caucasian & 1 & 0.13 & .714 & -.17 & 0.84 & 0.33 & 2.13 \\
\hline Gender & 1 & 2.41 & .120 & .39 & 1.47 & 0.90 & 2.40 \\
\hline Public Assistance & 1 & 0.04 & .847 & -.08 & 0.93 & 0.43 & 2.01 \\
\hline PBC Discipline & 1 & 0.08 & .775 & -.00 & 1.00 & 0.97 & 1.02 \\
\hline ECBS Challenging & 1 & 25.08 & $.000 * *$ & .17 & 1.19 & 1.11 & 1.27 \\
\hline PCS-A Parent & 1 & 6.38 & $.012 *$ & .07 & 1.08 & 1.02 & 1.14 \\
\hline PCS-A Child & 1 & 9.30 & $.002 * *$ & -.07 & 0.93 & 0.89 & 0. \\
\hline
\end{tabular}

Notes: $* p \leq .05 . * * p \leq .001$

The Journal of Genetic Psychology, Vol. 177, No. 2 (March/April 2016): pg. 44-54. DOI. This article is (C Taylor \& Francis (Routledge) and permission has been granted for this version to appear in e-Publications@Marquette. Taylor \& Francis (Routledge) does not grant permission for this article to be further copied/distributed or hosted elsewhere without the express permission from Taylor \& Francis (Routledge). 